\title{
Yield components of hairy vetch (Vicia villosa Roth.) in different sowing technologies on acidic sandy soil
}

\author{
${ }^{1}$ Edit Kosztyuné Krajnyák - ${ }^{2}$ Béla Szabó $-{ }^{2}$ Sándor Vágvölgyi $-{ }^{2}$ Réka Bukta $-{ }^{1}$ Péter Pepó \\ ${ }^{1}$ University of Debrecen, Kerpely Kálmán Doctoral School, H-4032 Böszörményi Str.138. Debrecen \\ ${ }^{2}$ University of Nyíregyháza, Institute of Engineering and Agricultural Sciences, Department of Agricultural Sciences and Environmental \\ Managment, H-4400 Nyíregyháza, Sóstói Str. 31/b \\ krajnyak.edit@nye.hu
}

\begin{abstract}
SUMMARY
Nearly a quarter of the agricultural utilized area of our country is made up of sandy soils. Sandy soils are poor in nutrients, and, therefore, the effectiveness of farming is basically determined by the method of maintaining soil fertility and the fertilization practice.

The hairy vetch called Vicia villosa Roth (Sandy Roth.), also known as a sand pioneer, plays a significant role in the exploitation of sandy soils. Its cultivation was started in Hungary in the late 1800s. It is primarily used as green fodder, most recently as a green manure and as a soil protection plant. The lupine is grown mainly as a supportive plant, which was previously rye, and today it is triticale. The ratio of the two plants to each other and the spatial location of plants depend on the method of sowing.

The aim of our work was to present the yields of some of the grain grown in different sowing methods and some of its crops.
\end{abstract}

Keywords: acidic sandy soil, sustainable soil utilization, ecological farming, hairy vetch

\section{INTRODUCTION}

In Hungary, the protection and improvement of sandy soils and the preservation of their fertility deserve special attention, as about $20 \%$ of our utilized area can be found in sandy areas. There is a significant proportion of fruits, vegetables, tobacco and other plants that have a decisive influence on the care of the Hungarian population and the livelihoods of the rural population (Láng, 1973; Stefanovits, 1966). Stefanovits (1977) identified the acidic sandy soils in 2.8 million hectares. According to Várallyay (1989), $13 \%$ of Hungary's soils are strongly and $42 \%$ of them are moderately acidic. Egerszegi (1960) also finds in the same order of magnitude the area and the territorial distribution of the sandy soils in Hungary. The sandy soils of the Nyírség are estimated to be over 400,000 ha, more than four-fifths of which are classified as humus-poor soils.

Originally, these soils are generally poor in colloids, humus and nutrients. They are extremely sensitive to environmental harm or improper human intervention. Since the filtering, buffing and binding capacity of sandy soil are low, they do not provide adequate protection against soil contamination (Kádár, 1999; Németh, 1966). Because of the above, it is important not only for agriculture to care for sand soils, but also for the preservation of the environment and environmental protection and environmental management (Kádár et al., 2011). Soil organic matter content is only slowly changing. The Westsik crop rotation measurements in the long-term formation of humus draw attention to grain crops. After 70 years, in the straw-fertilized treatment, higher organic matter content was measured than in those experiments where substitution of organic matter was replaced by lupine green or root fertilizer instead of straw fertilizer. (Lazányi, 2001).
According to Vágvölgyi et al. (2018), there is a relatively small number of crops that can be grown in sand farming, and in the case of leguminous crops in Hungary, the cultivated species of the Leguminous and Lupine genus and the sand-alfalfa are significant. The hairy vetch is the plant of sour sandy soil with excellent soil protection effect (Lazányi, 1999). The hairy vetch is an alternative leguminous fodder planted on the calcic sand of the Great Plain and on the sands of the Nyírség (Dobránszki, 2002).

Its role in maintaining soil fertility has long been known for leguminous plants, although it has not yet been sufficiently utilized in practice. Several experiments prove that by introducing flowering plants, the demand for nitrogen fertilizers for seedlings can be significantly reduced (Borbély et al., 2007). Among the flowery plants the hairy vetch is unique since it provides a large amount of fixed nitrogen and easily decomposing organic material in the spring, so it is not exposed to the wash-off effect of the autumn-winter precipitation. Long-term, regular use of the grain cereal mixture changes the soil organic balance in a positive direction, although this can only be measured after many years. The advantages of limping can be observed in the year of cultivation (Gondola and Szabóné, 2010).

The hairy vetch is the plant of low fertility loose soils. It has a good result both on the Nyírség acidic soil and on the calcareous sandy soils between the River Danube and River Tisza. It is a small plant, which can be successfully cultivated on loose sandy soil (Grábner, 1956). The soil can contain a wide range of $\mathrm{pH}$, and the $\mathrm{pH}$ range is between 6-7. Adding stalk or triticale, it makes possible to utilize sandy soil in a convenient way (Gondola and Szabóné, 2010). In North America the hairy vetch is used widespread as a green manure or as a mulching in no-till cultivation. It has been particularly useful in no-till maize monoculture (Czapar et al., 2002). It was first 
cultivated in Europe in the 19th century in Germany. (Hanelt, 2001). In Hungary it was started only at the end of the 1800's. In the 1950's and 1960's it spread mainly as green fodder. Its sowing area reached 75000 hectares (Jánossy, 1971). At the beginning of the 1970 s, the area of production was reduced by largescale farming, down to 10000 hectares (Vágó, 1981). The hairy vetch is native in Pre-Asia, where it was an important weed for cereals. In Europe, everywhere from the Mediterranean to the Scandinavian Peninsula, Roth recorded the species descriptor in 1789. (Szabóné, 1995, 1997). The germination method of the speckled species is hypogeaic. Its sprouting is fast, but the plant develops relatively little green mass before winter. In the autumn-winter period, the growth of the plants over the ground is slow, almost only the root is developing. The spindle-shaped root grows long, branched lateral roots with a large number of rootstocks. The root mass is $30-35 \%$ of the mass of the adult plant above ground. In spring, growth of shoots is significantly increased and large green mass is formed (Antal et al., 1966). The hairy vetch - just like most other crops - requires granular structure seed bed. Soil preparation can be carried out by taking into consideration of the autumn cereal used as a "support plant" (Grábner, 1956). The hairy vetch is not cultivated in pure culture even for the production of seeds, because the stem is dead. Usually, it is only blended with mixtures that can serve as a support for the stem. Mostly they are mixed with cereals, ryer, on better soil with winter barley or winter wheat. (Radics, 2002). The experimental results and practical experience of Gondola-Szabóné (2010) clearly demonstrate the benefits of supporting herbaceous cultivation. Wheat, triticale and low-stem rye varieties (eg Varda, Kisvárdai low) are the most suitable for supporting. In case of independent sowing, the depth of the sowing is $6-8 \mathrm{~cm}$, with $4 \mathrm{~cm}$ in the mixing seedlings. Seed volume: $40-60 \mathrm{~kg} \mathrm{ha}^{-1}$ of pea $(1-1.5$ million germs) in clear crops, with $35-40 \mathrm{~kg} \mathrm{ha}^{-1}$ of pea (0.8-1.0 million germs). Its optimum sowing time is in cooler production areas between mid August and 5 September, in the lowland areas by 20 September. They are drawn with a grain-seed drill to $3-5 \mathrm{~cm}$, the row spacing is set to $12 \mathrm{~cm}$ (Radics, 2002). The climatic demand of the hairy vetch is varied widely and therefore its adaptability is excellent. It is not sensitive to temperature, its drought tolerance and its winter resistance is excellent (Grábner, 1956). The effect of butterfly flowering plants cannot be only explained by the the nitrogen uptake of Rhizobium strains in rootstocks. As a result of the invigorating soil life, the amount of other nutrients can be increased (Vágvölgyi et al., 2018). Its fertilizer demand is not high, it does not require organic fertilizer. The herbaceous stock is generally good for weed suppression. The role of the lintel in environmental management is manifested by maintaining and increasing soil fertility. Based on the above, we can agree with Gondola-Szabóné (2010) that the hairy vetch is a plant culture that can serve as a bases of other plant species on acidic soil.

\section{MATERIALS AND METHODS}

The Farmland of the University of Nyíregyháza currently manages 250 hectares of arable land. The conventionally utilized land is 112 ha and the remaining 138 ha have been converted to organic farming. Within this, in 2017, 13 tons of triticale and lichen cultivation were carried out, where our experiments were carried out (Figure 1).

Figure 1: Lot Number 152

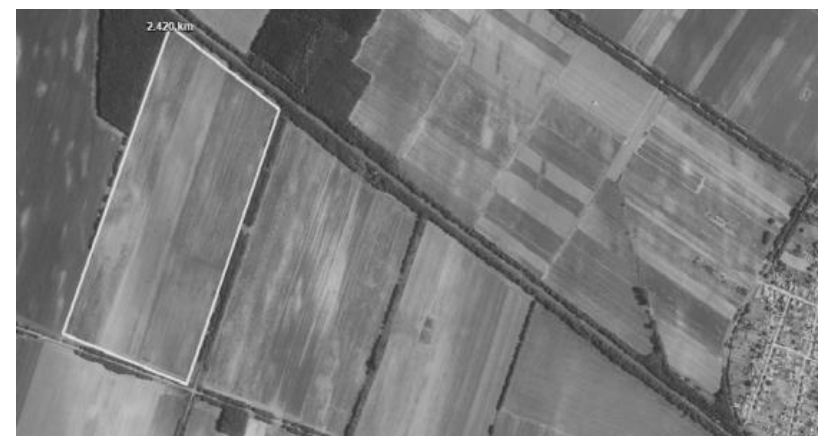

Source: https:/www.mepar.hu/mepar

The soil of the experimental area represents the weak nutrient and water-rich soils characteristic of the Nyírség region (Table 1). The data clearly shows that it is acidic, very loose, poor soil.

Table 1

The results of the soil examination of the experimental land (2015)

\begin{tabular}{|c|c|}
\hline Parameters examined & Measurement results \\
\hline Depth $(\mathrm{cm})$ & $0-30$ \\
\hline pH-KCI (-) & 4.26 \\
\hline Arany type number $\left(\mathrm{K}_{\mathrm{A}}\right)$ & 27 \\
\hline Soluble salt sum $(\mathrm{m} / \mathrm{m} \%)$ & $<0.02$ \\
\hline $\mathrm{CaCO}_{3}(\mathrm{~m} / \mathrm{m} \%)$ & $<0.1$ \\
\hline Organic material content $(\mathrm{m} / \mathrm{m} \%)$ & 0.80 \\
\hline $\mathrm{NO}_{3}^{-}-\mathrm{N}+\mathrm{NO}_{2}^{-}-\mathrm{N}\left(\mathrm{mg} \mathrm{kg}^{-1}\right)$ & 4.17 \\
\hline $\mathrm{SO}_{4}^{2-}-\mathrm{S}\left(\mathrm{mg} \mathrm{kg}^{-1}\right)$ & $<50$ \\
\hline $\operatorname{Mg}\left(\mathrm{mg} \mathrm{kg}^{-1}\right)$ & 116 \\
\hline $\mathrm{P}_{2} \mathrm{O}_{5}\left(\mathrm{mg} \mathrm{kg}^{-1}\right)$ & 160 \\
\hline $\mathrm{K}_{2} \mathrm{O}\left(\mathrm{mg} \mathrm{kg}^{-1}\right)$ & 141 \\
\hline $\mathrm{Na}\left(\mathrm{mg} \mathrm{kg}^{-1}\right)$ & 18.4 \\
\hline $\mathrm{Zn}\left(\mathrm{mg} \mathrm{kg}^{-1}\right)$ & 0.61 \\
\hline $\mathrm{Cu}\left(\mathrm{mg} \mathrm{kg}^{-1}\right)$ & 2.72 \\
\hline $\operatorname{Mn}\left(\mathrm{mg} \mathrm{kg}^{-1}\right)$ & 146 \\
\hline
\end{tabular}

Source: Hungarian Horticultural Propagation Material Non-profit Ltd.

Cultivation took place after the sowing of sweet potato. The variety of the hairy vetch was the Hungvillosa bred by Kisvárda. The valuable property of the variety is that it gives a large green mass on soils of low fertility early in the spring. It has a good overwintering, bushy and fertile ability. The supporting plant was the Titanium, triticale variety, which can be successfully grown on the fertile acidic 
sandy soils. Its yielding ability and tillering are excellent. Its height is moderate, its stem is strongly waxy. It is resistant to powdery mildew and yellow leaf foliage. Soil was prepared for sowing in September, we closed the shallow plowing with a combiner. The sowing was done in mid-September. We used two types of sowing methods. For blended sowing, $70 \mathrm{~kg}$ of triticale was mixed with $30 \mathrm{~kg}$ vetch seed per hectare. In order to prevent the separation of the seeds in the seed drum, we spent $100 \mathrm{~kg}$ of seed mixture at a time. For lattice sowing, the amount and ratio of lime and triticale was the same as mixing. The two species were sown into separate rows. The proportion of triticale and lintel rows was 6: 2 . The stock started in the autumn. After late winter we got a well-developed stock in spring (Figure 2).

Figure 2: The experimental stand in different feno phases

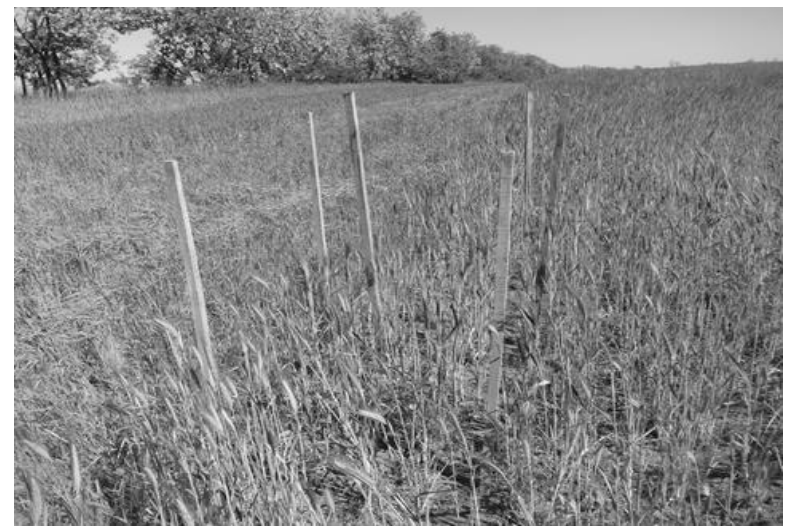

(Photo: Kosztyuné K. E.)

Since our experiment was carried out in an ecological farming area, no fertilizer or pesticides were used during cultivation. During the growing season, observations and measurements were made on the production of the hairy vetch twice. In both methods, $1 \mathrm{~m}^{2}$ parcels were designated in 4 repetitions. At the time of budding (7 May, 2018) we measured the mass of the plants under ground and ground biomass. The same measurements were made directly prior to harvest (28 June 2018). A 4 x 100 m long, $6 \mathrm{~m}$ wide parcel was designated in the crop table, which was harvested separately with a combine harvester. The amount of yield was calculated per hectare. The yields of the crops from the harvester

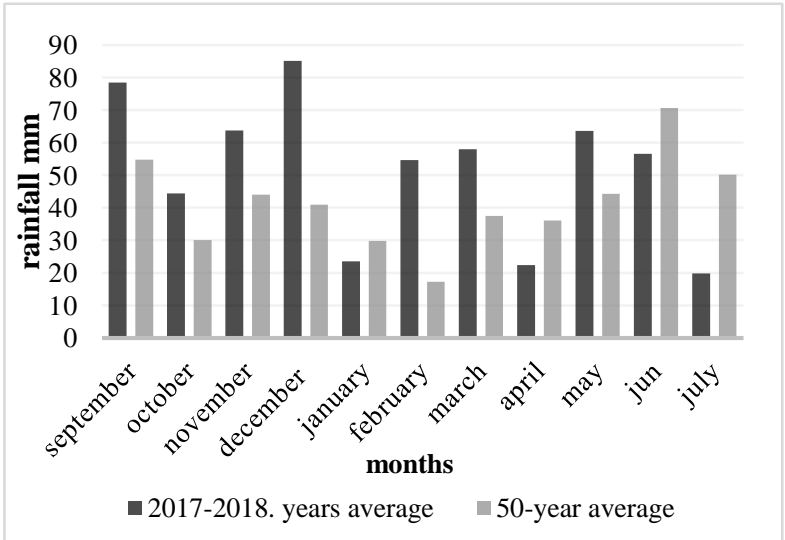

Source: measurements done by DE AKIT Nyíregyháza Research Institute

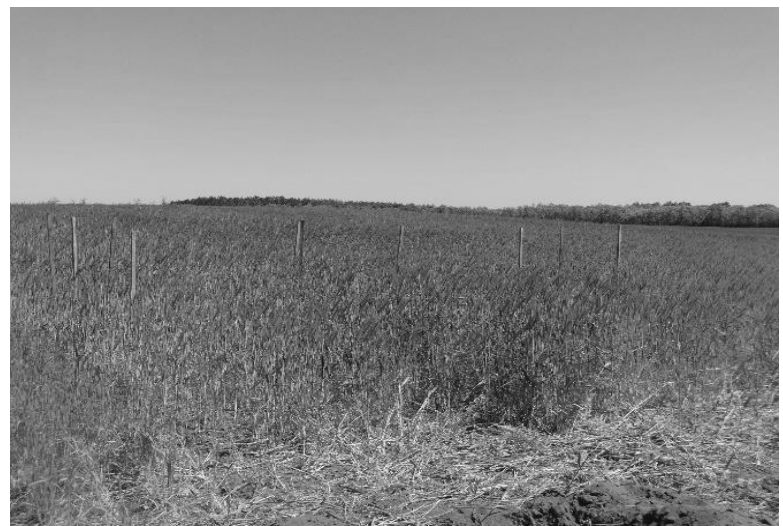

were determined by the ratio of the seed yield of triticale and hairy vetch. The statistical evaluation of the results was done using the SPSS biometric analysis method.

The weather conditions of the experimental years are characterized by the precipitation and temperature data (Figures 3, 4).

The meteorological data were recorded on the data of the DE AKIT Nyíregyháza Research Institute. The measured values are always compared to the 50-year average.

Figure 4: Evolution of the monthly average temperature data of the growing season

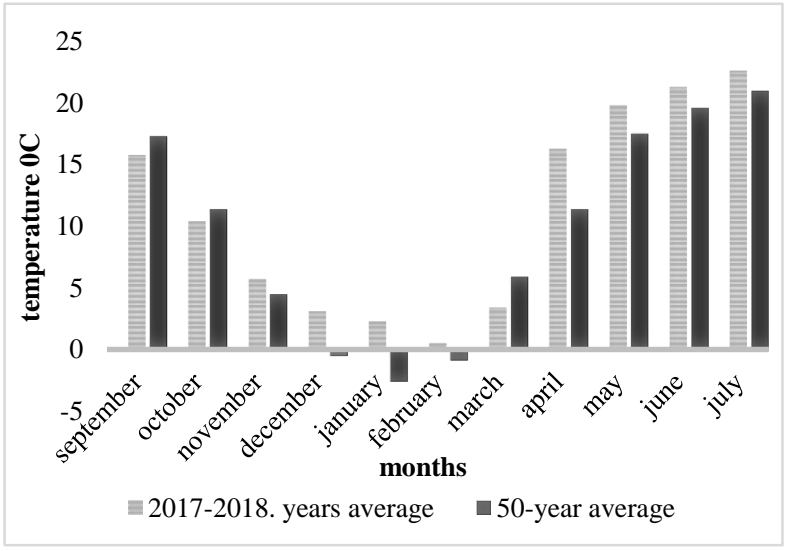

Source: measurements done by DE AKIT Nyíregyháza Research Institute 


\section{RESULTS AND DISCUSSION}

During the vegetation period, the growth of the subterranean and irradiated parts of the hairy vetch was constantly changing. In our experiment we compared the relative and relative proportions of the root mass and the biomass above ground in two times (Table 2).

At the same time the total amount of biomass was almost identical in both sowing modes. The amount of root weight measured during the budding of the hairy vetch was slightly above the green weight over the ground in mixed crops. When harvested, the biomass above ground was nearly one-half times higher than the root mass in both sowing modes. The yield of all the biomass of the hairy vetch during harvest time was more than twice that of the budding value.

The data of the $600 \mathrm{~m}^{2}$ seed crop harvested on a length of $100 \mathrm{~m}$ in a width of a combine harvester $(6$ $\mathrm{m})$ are summarized in Table 3 .

The biomass yield of roots on and above ground parts measured at budding and harvesting in different sowing methods

\begin{tabular}{|c|c|c|c|c|c|c|}
\hline \multirow[b]{2}{*}{$\begin{array}{l}\text { Sowing method/number of } \\
\text { repetations }\end{array}$} & \multicolumn{3}{|c|}{7 May 2018.} & \multicolumn{3}{|c|}{28 June 2018.} \\
\hline & $\begin{array}{l}\text { Root mass } \\
\mathrm{kg} \mathrm{m}^{-2}\end{array}$ & $\begin{array}{c}\text { Above } \\
\text { ground mass } \\
\mathrm{kg} \mathrm{m}^{-2}\end{array}$ & $\begin{array}{c}\text { Sum of } \\
\text { biomass } \\
\mathrm{kg} \mathrm{m}^{-2}\end{array}$ & $\begin{array}{l}\text { Root mass } \\
\mathrm{kg} \mathrm{m}^{-2}\end{array}$ & $\begin{array}{l}\text { Above ground } \\
\text { mass } \\
\mathrm{kg} \mathrm{m}^{-2} \\
\end{array}$ & $\begin{array}{c}\text { Sum of } \\
\text { biomass } \\
\mathrm{kg} \mathrm{m}^{-2}\end{array}$ \\
\hline Mixed sowing/I. & 0.23 & 0.18 & 0.41 & 0.36 & 0.62 & 0.98 \\
\hline Mixed sowing/II. & 0.26 & 0.18 & 0.44 & 0.43 & 0.57 & 1.00 \\
\hline Mixed sowing/IV. & 0.21 & 0.24 & 0.45 & 0.32 & 0.51 & 0.83 \\
\hline Average & 0.23 & 0.21 & 0.44 & 0.35 & 0.54 & 0.89 \\
\hline Strip sowing/I. & 0.28 & 0.16 & 0.44 & 0.30 & 0.45 & 0.75 \\
\hline Strip sowing/II. & 0.39 & 0.14 & 0.53 & 0.37 & 0.63 & 1.00 \\
\hline
\end{tabular}

The yields of the triticale-hairy vetch ratios in mixed and striped crops

\begin{tabular}{|c|c|c|c|c|c|c|c|c|}
\hline \multicolumn{9}{|c|}{ Mixed sowing (triticale - hairy vetch) } \\
\hline $\begin{array}{l}\text { Number of } \\
\text { repetations }\end{array}$ & $\begin{array}{l}\text { Yield per parcel } \\
\text { kg } 100 \mathrm{~m}^{-1}\end{array}$ & $\begin{array}{c}\text { Triticale * } \\
\%\end{array}$ & $\begin{array}{c}\text { Hairy Vetch* } \\
\%\end{array}$ & $\begin{array}{c}\text { Triticale } \\
\mathrm{kg} 100 \mathrm{~m}^{-1}\end{array}$ & $\begin{array}{l}\text { Hairy Vetch } \\
\text { kg } 100 \mathrm{~m}^{-1}\end{array}$ & $\begin{array}{c}\text { Total } \\
\text { Yield } \\
\text { kg ha-1 }^{-1}\end{array}$ & $\begin{array}{l}\text { Triticale } \\
\mathrm{kg} \mathrm{ha}^{-1}\end{array}$ & $\begin{array}{l}\text { Hairy } \\
\text { Vetch } \\
\mathrm{kg} \mathrm{ha}^{-1}\end{array}$ \\
\hline I. & 160.0 & 78.0 & 22.0 & 124.8 & 35.2 & 2666.0 & 2079.0 & 587.0 \\
\hline II. & 116.0 & 80.1 & 19.9 & 93.0 & 23.0 & 1933.0 & 1548.0 & 385.0 \\
\hline III. & 158.0 & 74.8 & 25.2 & 118.2 & 39.8 & 2632.0 & 1969.0 & 663.0 \\
\hline IV. & 114.0 & 81.2 & 18.8 & 92.6 & 21.4 & 1899.0 & 1542.0 & 357.0 \\
\hline Áverag & 137.0 & 78.5 & 21.5 & 107.5 & 29.5 & 2283.0 & 1792.0 & 491.0 \\
\hline \multicolumn{9}{|c|}{ Strip sowing (triticale - hairy vetch) } \\
\hline $\begin{array}{l}\text { Number of } \\
\text { repetations }\end{array}$ & $\begin{array}{l}\text { Yield on parcel } \\
\mathrm{kg} 100 \mathrm{~m}^{-1}\end{array}$ & $\begin{array}{c}\text { triticale } * \\
\%\end{array}$ & $\begin{array}{c}\text { hairy vetch* } \\
\%\end{array}$ & $\begin{array}{c}\text { triticale } \\
\mathrm{kg} 100 \mathrm{~m}^{-1}\end{array}$ & $\begin{array}{l}\text { hairy vetch } \\
\mathrm{kg} 100 \mathrm{~m}^{-1}\end{array}$ & $\begin{array}{l}\text { sum yield } \\
\mathrm{kg} \mathrm{ha}^{-1}\end{array}$ & $\begin{array}{l}\text { triticale } \\
\mathrm{kg} \mathrm{ha}^{-1}\end{array}$ & $\begin{array}{l}\text { hairy vetch } \\
\mathrm{kg} \mathrm{ha}^{-1}\end{array}$ \\
\hline I. & 184.0 & 80.8 & 19.2 & 148.7 & 35.3 & 3065.0 & 2477.0 & 588.0 \\
\hline II. & 118.0 & 81.2 & 18.8 & 95.8 & 22.2 & 1966.0 & 1596.0 & 370.0 \\
\hline III. & 158.0 & 86.5 & 13.5 & 136.7 & 21.3 & 2632.0 & 2277.0 & 355.0 \\
\hline IV. & 176.0 & 85.7 & 14.3 & 150.8 & 25.2 & 2932,0 & 2513.0 & 419.0 \\
\hline Average & 159.0 & 83.5 & 16.5 & 133.0 & 26.0 & 2649 & 2212.0 & 437.0 \\
\hline
\end{tabular}


In the average of four repetitions, striped sowing gave higher yields. By random sampling of the combine-free raw material, by selecting the hairy vetch and triticale seeds, the proportion of triticale in the strip sowing significantly exceeded the proportion in mixed sowing. The sowing rate of the two components of the mixture (2.33) increased significantly during the harvest as the triticale increased to (3.65-5.06). Larger seed volumes per hectare were obtained in strip sowing, where the triticale ratio was higher, but our results are not statistically verifiable. The seedlings of the hairy vetch were mixed in mixed crops, where the amount of total yield was lagging behind. This can not be justified statistically either. The experimental year is characterized by extreme weather data that can not be ignored when the results are interpreted. The amount of precipitation from sowing to winter time was significantly above the 50 -year average by $101.8 \mathrm{~mm}$. This trend continued in February and March (57.8 $\mathrm{mm})$. This rainy season coincided with the intense autumn and early spring erosion of the lizard. Average values for autumn temperatures did not significantly deviate from the 50-year average. From the time of late dressing to harvest, the monthly average temperature significantly exceeded the 50 year average $\left(1.5-4.9^{\circ} \mathrm{C}\right)$.

\section{CONCLUSION}

Our most important conclusions can be summarized below. In favour of favourable precipitation conditions, at the beginning of the vegetation period, the development of the root mass of the hairy vetch is well above the development of the parts above the earth. This result is identical to those of Antal et al. 1966 as well as Gondola-Szabóné (2010). Due to the high precipitation and the higher average temperatures, the development of parts above the ground is very intense until the end of the budding. The same opinion was given by Szabóné Csalló K (1997). The proportion of components in lattice significantly changes in the favour of triticale lane seed. The production of triticale and hairy vetch in the year 2018 was modest, probably due to the extreme temperature of the spring months. Due to the overaverage temperature over the months, the low-humus acidic sandy soil is depleted over a short period of time.

\section{REFERENCES}

Antal, J-Egerszegi, S.-Penyigei, D. (1966): Növénytermesztés homokon. Mezőgazdasági Kiadó, Budapest.

Borbély, F.-Vágvölgyi, S.-Romhány, L. (2007): A Napraforgó zöldtrágyázása csillagfürttel. In.: Iszályné, T.J. (szerk.) Debreceni Egyetem Agrár- és Müszaki Tudományok Centruma Kutató Központ Nyíregyháza 1927-2007. 80. évi Jubileumi Kiadvány. DE AMTC Kutató Központ, Nyíregyháza p. 454459.

Czapar, G. F.-Simmons, F. W.-Bullock, D. G. (2002): Delayed control of a hairy vetch (Vicia villosa Roth) cover crop in irrigated corn production. Crop protection 21, 507-510. pp.

Dobránszki, J. (szerk.) (2002): A szöszösbükkönytermesztés technológiája. In: A Nyírségi burgonyatermesztés fejlesztése, homokhasznosítás tájba illő növényekkel. Nyíregyháza pp 206 214.

Egerszegi, S. (1960): A homok mély termőrétegének kialakítása Kandidátusi disszertáció. MTA TMB. Budepest. Kézirat.

Gondola, I.-Szabóné, Cs. K. (2010): Szöszösbükköny (Vicia villosa Roth.). In: Gondola: Az alternatív növények szerepe az Észak-alföldi Régióban, 131-151. Nyíregyháza.

Grábner, E. (1956): Szántóföldi növénytermesztés. Mezőgazdasági Kiadó. Budapest.

Hanelt, P. (2001): Mansfeld's Encyclopedia of Agricultural and Horticultural Crops. Institute of Plant Genetics and Crop Plant Research. Original German edition published by Akademie Verlag, Berlin an Springer-Verlag, Berlin Heidelberg New York, 1986. $3700 \mathrm{p}$.

Jánossy, A. (1971): A Vicia-fajok termesztése és nemesítése Bükkönytermesztés. In.: Mándi Gy. (Ed) A Vicia fajok termesztése és nemesítése, Akadémiai Kiadó. Budapest.

Kádár, I. (1999): Tápanyaggazdálkodás Magyarország homoktalajain. IPI-MTA TAKI. Budapest.
Kádár, I.-Szemes, I.-Loch, J.-Láng, I. (2011): A nyírlugosi mütrágyázási tartamkísérlet 50 éve. Magyar Tudományos Akadémia Talajtani és Agrokémiai Kutatóintézete, Budapest.

Lakanen, E.-Erviö, R.: (1971): A comparison of eight extractants for the determination of plant available micronutrients in soils. Acta Agr. Fenn. 123: 223-232.

Láng, I. (1973): Mütrágyázási tartamkísérletek homoktalajokon. Doktori Disszertáció. MTA. Budapest.

Lazányi, J. (1999): Hairy vetch (Vicia villosa Roth.) In: Agrucultural Research in Nyírség Region. Research Centre of Debrecen Agricultural University (Ed Lazányi J. Dobrányszki J.) $106-108 \mathrm{p}$.

Lazányi, J. (2001): A Nyírség Mezőgazdasága. A homoki gazdálkodás fenntartható rendszere a Westsik vetésforgó kísérlet tapasztalatai alapján. Debreceni Egyetem ATC Kutató Központja, Nyíregyháza.

Németh, T. (1966): Talajaink szervesanyag-tartalma és nitrogénforgalma. MTA TAKI. Budapest.

Radics, L. (2002): Alternatív növények termesztése II. Szaktudás Kiadó Ház, Budapest. 54-60.

Stefanovics, P. (1966): Hazánk homoktalajainak jellemzése. In: Növénytermesztés homokon. (Szerk Antal, J.) 9-22. Mezőgazdasági Kiadó, Budapest.

Stefanovics, P. (1977): Talajvédelem, környezetvédelem. Mezőgazdasági Kiadó, Budapest.

Szabóné Csalló, K. (1995): A szöszösbükköny (Vicia villosa) és a tavaszi bükköny (Vicia sativa) nemesítése a genetikai variánsok felhasználásával. MTA Szabolcs-Szatmár-Bereg megyei Tudományos Testületének kiadványa. Nyíregyháza. 1995. október 1 .

Szabóné Csalló, K. (1997): A bükkönyfélék (Vicia faba L., Vicia villosa és a Vicia sativa) nemesítése és hasznosításuk. 
Tiszántúli Mezőgazdasági Tudományos Napok Kiadványa. DATE Kutató Intézete Karcag. 1997. június 12-13.

Vágó, M. (1981): Szöszösbükköny (Vicia Villosa). In.: Szabó J. (Ed): A szántóföldi növények vetőmagtermesztése és fajtahasználat. Mezőgazdasági Kiadó. Budapest 427-434.

Vágvölgyi, S.-Szabó, B.-Kosztyuné, K. E. (2018): A pillangósvirágú takarmánynövények jelentősége a savanyú homoktalajok fenntartható hasznosításában. In: Hangsúlyok a térfejlesztésben. (Szerk. Nagy J.) 399-409.

Várallyay, Gy. (1989): Soil degradation processes and their control in Hungary. Land degradation and rehabilitation. 1. 171-188. pp Gödöllö. 